evidence for de novo protein synthesis mediated by glucocorticoid receptors. Endocrinology 112:829-837

22. Barnes PJ, Karliner JS, Dollery CT 1980 Human lung adrenoreceptors studied by radioligand binding. Clin Sci 58:457-461

23. Maier JA, Roberts JM, Jacobs MM 1989 Ontogeny of fetal adenylate cyclase: mechanisms for regulation of beta adrenergic receptors. J Dev Physiol 12:1025-1034

24. Ballard PL, Hawgood S, Liley H, Wellenstein G, Gonzales LW, Benson B, Cordell B, White RT 1986 Regulation of pulmonary surfactant apoprotein SP 28-36 gene in fetal human lung. Proc Natl Acad Sci USA 83:9527-9531
25. Whitsett JA, Pilot T, Clark JC, Weaver TC 1987 Induction of surfactant protein in fetal lung. J Biol Chem 262:5256-5261

26. Odom MJ, Snyder JM, Boggaram V, Mendelson CR 1988 Glucocorticoid regulation of the major surfactant associated protein (SP-A) and its messenger ribonucleic acid and of morphological development of human fetal lung in vitro. Endocrinology 123:1712-1720

27. Smith BT, Sabry K 1983 Glucocorticoid-thyroid synergism in lung maturation: a mechanism involving epithelial-mesenchymal interaction. Proc Natl Acad Sci USA 80:1951-1954

\title{
Announcement
}

\section{LABCATAL Prize to Promote Scientific Research in Field of Trace Elements}

A 1st prize of 35000 French francs and three 2nd prizes of 5000 French francs each will be awarded by the French company, Laboratoires LABCATAL, for scientific works on trace elements in the field of pharmacology or human therapeutics.

These prizes will be presented to winners at the scientific congress organized by the French Society for Essential Trace Element Study (SFERETE) in Les Deux-Alpes, France, January 14-18, 1991.

For further information on the LABCATAL prizes, please contact the Scientific Director, Laboratoires LABCATAL, 7 rue Roger Salengro, B.P. 305, 92541 Montrouge Cedex, France.

For further information concerning the congress organized by the SFERETE, please contact: Mrs. A. Alcaraz, Hopital A. Michallon, Laboratoire de Biochimie C, B.P. 217 X, 38043 Grenoble Cedex, France. 